\title{
A Language-Based Theory OF LEARNING IN THE DISCIPLINES ANd For Acting in Social Life
}

\author{
UNA TEORía BASAdA EN EL LENGUAJE PARA EL APRENDIZAJE EN LAS DISCIPLINAS \\ Y LA ACCIÓN SOCIAL
}

UNE THÉORIE BASÉE SUR LA LANGUE VISANT L'APPRENTISSAGE DANS LES DISCIPLINES ET POUR AGIR DANS LA VIE SOCIALE

\author{
Andrés Ramírez \\ Ed. D. Language, Literacy and Culture, \\ University of Massachusetts, USA. \\ Associate Professor, Curriculum, \\ Culture, and Educational Inquiry \\ Department, Florida Atlantic \\ University, USA. \\ ramirezi@fau.edu \\ https://orcid. \\ org/0000-0002-6335-2041
}

\section{Estela I. Moyano}

Ph. D. Linguistics, Universidad de Buenos Aires, Argentina. Professor, Universidad Nacional de General Sarmiento, Universidad Nacional Guillermo Brown, Universidad de Flores, Argentina. estelaimoyano@gmail.com https://orcid.

org/0000-0003-3493-0778

\section{J. R. Martin \\ Ph. D. Linguistics, University of Essex, UK. \\ Professor of Linguistics (Personal Chair), Department of Linguistics, University of Sydney, Australia. james.martin@sydney.edu.au https://orcid. \\ org/0000-0003-3493-0778}

Since its emergence in the 1960s, systemic functional linguistics (SFL), like any other linguistic theory, has tried to seek answers to questions about the nature of language. But SFL is distinct from most other linguistic theories because since its origins it sees theory as problem-driven, and has been developed as "a linguistic theory that takes responsibility for language problems and develops theory in relation to such issues" (Martin, 2013, p. 239). This dialectic has fostered collaboration across disciplines, in particular between SFL and sociology. This joint work began in the 1960s in London through the association of linguists Michael Halliday and Ruqaiya Hasan with sociologist Basil Bernstein, and continues to the present day via exchanges between SFL and Karl Maton's Legitimation Code Theory (Martin et al., 2020). Bernstein (1995) credits Halliday and Hasan with making it possible for him to think about linguistics in sociological terms and sociology in linguistic terms. He felt this was enabled by Halliday's development of a perspective on language in which there was no dichotomy between langue and parole. For Halliday, Bernstein notes, "There is system potential and textual actualization: one not two different orders” (Bernstein, 1995, p. 398).

Halliday in turn credits Bernstein with re-kindling a longstanding sense of social purpose for work in SFL. At the first North American International Systemic Functional Conference, held at York University in Toronto in 1982, Halliday comments on his collaboration with Bernstein as follows: "From Bernstein I learnt, also, for the second time in my life, that linguistics cannot be other than an ideologically committed form of social action" (Halliday, 1985, p. 5). Reflecting

https://doi.org/10.17533/udea.ikala.v26n01a12 
on this very remark, 32 years later, Martin agrees: "I doubt very much that SFL could have survived, let alone evolved and thrived, without a serious political commitment of this order" (Martin, 2014, p. 21).

In conversation with Ruqaiya Hasan, Gunther Kress, and Jim Martin, Halliday characterises Bernstein's contribution in terms of the provision of a coherent and committed theory of social structure, which provided a powerful interpretative framework linking educational failure to social class. Halliday adds: "In a society like the current western societies with very strong hierarchical structures of class... he [Bernstein] asked 'How were these, in fact, transmitted, maintained? What essentially is the nature of these hierarchies as semiotic constructs?" (Martin, 2013, p. 125). Thus, when experts describe SFL as a multifaceted theory of language with a robust interconnected linguistic architecture involving axis, metafunction, stratification, rank, and its instantiation in texts (i.e., Doran, 2018; Matthiessen \& Halliday, 2009), they do so not just as an elaboration of SFL theory but in order to foster the development of an ever more appliable linguistics. Appliability, which in traditional linguistic circles might be regarded as a sign of "theoretical impurity” (Halliday \& Matthiessen, 2014, p. xviii), was thus transformed into the socially committed heart of Halliday's conception of linguistic theory.

Following Bernstein's interest in pedagogical issues, it is not surprising that one of the fields in which SFL's appliability has found one of its most productive sites of intervention is education. SFL's proposals are ambitious ones and have involved an unparalleled adaptability across diverse geographical, linguistic, and educational contexts. The genre-based literacy programs of the so-called Sydney School (Rose \& Martin, 2012; Derewianka \& Jones, 2012; de Silva Joyce \& Feez, 2012) have led the way as far as these SFL interventions are concerned. Central to these initiatives has been the identification of the genres every student needs to learn to write in their specific disciplinary contexts as well as the development of a pedagogy that ensures access for all students regardless of their background.

Two aspects of these literacy programs will be highlighted here. One has to do with the relationship between school genres and workplace genres established during the Write it Right project (Christie \& Martin, 1997; Veel, 2006). This action-research initiative demonstrated that failing to master key genres of learning has potentially debilitating consequences not only for progress through formal schooling but also for opportunities in the workplace outside. The second has to do with the kind of teaching/learning interaction that facilitates student control of genres. The Sydney School's guiding principle in this regard was "guidance through interaction in the context of shared experience". This principle was implemented through the development of a range of teaching/learning cycles which placed teachers in a mentoring role approximating the scaffolding provided by caregivers during first language learning in the home (Painter, 1984, 1991).

The democratizing educational project promoted by the Sydney School of genre pedagogy is reviewed in Rose and Martin (2012). This book outlines the major genres implicated in primary and secondary school discourse, across subject areas, in addition to the major teaching/learning cycles developed to teach them. Central to thiswork istheunderstanding that language is essential in all learning-including learning to read and write across disciplines. In fact, one of Michael Halliday's most important contributions had to do with his vision of a language-based theory of learning (Halliday, 1993). Such a theory, Halliday contends, would involve three dimensions: learning language, learning through language, and learning about language (Halliday, 2004). These dimensions are reflected in various ways in Sydney School pedagogy around the world (Dreyfus et al., 2016; Harman, 2018; Kartika-Ningsih, 2016; Moyano, 2007, 2010, 2017, forthcoming; Ramírez, 2018, 2020, forthcoming; Urrejola-Coral \& Vidal Lizama, forthcoming; among others). The key to their successful implementation has been the understanding that to be successful 
literacy curriculum and pedagogy have ultimately to be embedded in disciplines-because the distinctive language patterns of each discipline build their knowledge in distinctive ways. This has to be respected as the language of their specialized suite of genres is acknowledged, appreciated for its functionality, and accessibly taught.

The bulk of the articles included in this special issue of Ikala focus on educational interventions in different disciplinary contexts-including computer science, constitutional law, English, Náhuatl poetry, and language teaching methodology, among others. They also present applications across primary and secondary settings in Latin America and North America and beyond (Argentina, Brazil, Canada, Chile, Colombia, Indonesia, Mexico, and the Solomon Islands).

The papers have been written in Spanish and English and can be organised in different groups according to levels of schooling. The first group comprises experiences in primary school across different contexts. In the first paper, "Incidence of Multimodality and Genre-based Pedagogy on Second Grade Students' Writing of Descriptive Reports", written in Spanish, Carmen Luz Maturana and Bárbara Gálvez describe an intervention and its achievements in the second grade in a Chilean school. Their main purpose is to show how students from a disadvantaged group, most of them immigrants from Haiti, develop texts that describe a fantastic beast they have drawn and written about. Accordingly, they deal with multimodality in relation to genre pedagogy in the writing of descriptive reports. The corpus includes student's texts written before and after the implementation of the Teaching Learning Cycle (Martin, 1999).

In the second paper, "SFL in Solomon Islands: A Framework for Improving Literacy Practices in Primary School", Marie Quinn describes how principles of SFL theory were embedded in new English teaching materials for the early years of primary school and how these principles were used in teacher-training practices in order to reform literacy pedagogy in the South Pacific. The paper suggests that the students improved in their writing abilities, although these results have not yet been published anywhere, according to the author.

The second group of papers is about interventions in secondary school. The first article of this group is authored by José David Herazo and colleagues. They report on the application of Reading to Learn (R2L) in the context of teaching English as a second language in the $9^{\text {th }}$ grade of a rural school. The paper, titled "Reading to Learn and EFL Student's Construction of Spoken Biographical Recounts", shows that learner's spoken meaningmaking potential increased taking into account different levels of language and genre. The use of metalanguage is highlighted as a key scaffolding resource in their students' independent construction of the texts.

The next paper, "Intermodality and Multilingual Re-instantiation: Joint Construction in Bilingual Genre Pedagogy”, by Harni Kartika-Nighsih and David Rose, gives account of an R2L bilingual program in two EFL biology classrooms from two different schools in Bandung, Indonesia. This project involved the production of teaching materials and classroom instruction in spoken Bahasa Indonesia and English. The paper focuses on the Joint Construction stage of the program and shows how a carefully designed focus on intermodality and multiliguism contributes to the development of autonomous skills in L2 science writing.

The last paper of this group is from Orlando Vian Jr. and Fabiane Dalben de Faria, and is entitled "Genre-Based Pedagogy in Paulo Freire's Country: Teaching Brazilian Students to Write Essays for the National High School Exam”. It discusses how a large cohort of students from two different schools applied appraisal resources to align with their readers in texts written as preparation for a national exam, using R2L methodology. The paper notes the importance of mastering language resources in development literacy and establishes a connection between the 
Sydney School genre-based pedagogy and Paulo Freire's critical pedagogy.

The third group of papers represents experiences and reflections on literacy in higher education. The first paper of this group, written in Spanish, is devoted to the promotion of literacy skills related tolearning in the disciplines. It is written in Spanish by Cecilia Serpa, and is titled "Teaching Writing in Higher Education: A Pedagogical Experience with the 'Flow Chart Description' Macro-Genre". The paper shows evidence of the results of applying an adapted version of the Teaching-Learning Cycle (Moyano, 2007) to a subject called Computerbased Tools and Programming for Engineering and Science taught at a university in Argentina. First of all, the macro-genre the students had to write is described, then the sequence of teaching is explained and finally the results of the process are presented in terms of evolution of two different versions of the texts. The results show the effectiveness of the process of the pedagogic pro14 posal described.

The second paper of this group is "Pre-Service EFL Teachers' Responses to a Systemic Functional Linguistics Pedagogical Unit: An Experience in a Public University in Colombia", authored by Yenny Chavarría and Doris Correa. The paper presents the results of a three-month intervention oriented to prepare pre-service teachers to teach functional grammar instead of traditional grammar. The concomitant case study explores the responses of these students to the instruction. The data obtained show that students move from resistance, to cautious acceptance, to openness-but not along a direct path. Their results show that the transition from traditional grammar to a functional perspective is possible. The results also suggest the need to identify strategies to encourage the more cautious or resistant students.

The third paper, "Fostering Written Production of Review Texts among EFL University Students Through a Genre-Based Approach", by Diana Durán-Bautista, focuses on the effects of a genrebased approach, adapted from the Teaching
Learning Cycle (Rose \& Martin, 2012), in the production of review texts in a pre-intermediate English course in Colombia. The proposal gives prominence to the students' active participation in systematic peer feedback-designed to give them more independence from the teacher. The effects of the process were evaluated through an ethnographic methodology, and the findings suggest acceptance of the implementation and full comprehension of its aims.

Next, the paper from Laura Hernández and Jessica Delgado, “Teaching Náhuatl Through Poetry: A Didactic Intervention Using the GenreBased Pedagogy Reading to Learn”, presents in Spanish a project designed to teach Náhuatl as a second language using R2L methods in a Master's program at a Mexican university. The project highlights the importance of the reappraisal of an indigenous language by focusing on its resources in order to teach literacy skills. The paper presents positive results as far as the effectiveness of the methodology implemented is concerned.

The fifth paper in this section, "Textual Metafunction: A Basis for Academic Literacy in Constitutional Law", written by Ilene Rojas García in Spanish language, addresses the imperative of training for reading in the disciplines in a higher education setting and uses genre-based pedagogy on this endeavor (Rose \& Martin, 2012). The article describes the Theme-Rheme patterns at the lexico-grammatical stratum, as well as the PERIODICITY discourse-semantic system of four texts used as study material in a Constitutional Law course taught at a higher education institution in Colombia. These analyses became the linguistic backdrop for the design of explicit teaching of the Explanation genre (Martin \& Rose, 2008) identified by the author as a key genre in the course.

Last but not least, the final paper of this special volume is "Pomp and Circumstances: From research, in practice, for students". Written by Jennifer Walsh Marr and Jodie Martin, this theoretical paper clearly highlights the value of circumstances 
for teaching academic literacy. The authors explore how circumstances (i.e., clause functions concerned with location in space and time, manner, cause, condition, etc.) contribute to students' comprehension of complex academic texts and to their written production. The paper provides detailed insights on how circumstance can generate crucial insights for students as they seek to comprehend complex academic materials and write discipline-appropriate texts.

Overall, this special issue of Íkala features educational applications that develop SFL genre-based pedagogy in valuable directions, drawing on SFL's modelling of language and social context. The volume is centred on Halliday's vision of a language-based theory of learning across disciplines and diverse linguistic and cultural contexts, thereby enacting a range of appliable linguistics practice informed by SFL.

\section{References}

Bernstein, B. (1995). A response, in A. R. Sadovnik (Ed.), Knowledge and pedagogy: The sociology of Basil Bernstein (pp. 385-424). Ablex.

Christie, F. \& Martin, J. R. (Eds.) (1997). Genre and institutions. Social processes in the workplace and school. Continuum.

De Silva Joyce, H. \& Feez, S. (2012). Text-based language and literacy education: Programming and methodology. Phoenix Education.

Derewianka, B. \& Jones, P. (2012). Teaching language in context. Oxford University Press.

Doran, Y. J. (2018). The discourse of physics: Building knowledge through language, mathematics and image. Routledge. https://doi. org/10.4324/9781315181134

Dreyfus, S., Humphrey, S., Mahboob, A. \& Martin, J. R. (2016). Genre pedagogy in higher education. The SLATE project. Palgrave McMillan. https://doi. org/10.1007/978-1-137-31000-2

Halliday, M. A. K. (1985). Systemic background. In J. D. Benson \& W. S. Greaves (Eds.), Systemic perspectives on discourse: Selected theoretical papers from the $9^{\text {th }}$ International Systemic Workshop (pp. 1-15). Ablex.
Halliday, M. A. K. (1993). Towards a language-based theory of learning. Linguistics and Education, 5, 93-116. https://doi.org/10.1016/0898-5898(93)90026-7

Halliday, M. A. K. (2004). Three aspects of children's language development: Learning language, learning through language, learning about language. In J. Webster (Ed.), The language of early childhood. Collected Works of M. A. K. Halliday (vol. 4, pp. 308-326). Continuum.

Halliday, M. A. K. \& Matthiessen, C. M. I. M. (2014). An introduction to functional grammar ( $4^{\text {th }} \mathrm{ed}$.). Arnold. https://doi.org/10.4324/9780203431269

Harman,R.(2018). Bilinguallearnersandsocialequity. Springer. https://doi.org/10.1007/978-3-319-60953-9

Kartika-Ningsih, H. (2016). Multilingual re-instantiation: Genre pedagogy in Indonesian classrooms. (Unpublished Ph. D. thesis). The University of Sydney, Australia.

Martin, J. R. (1999). Mentoring semogenesis: 'Genre-Based' literacy pedagogy. In F. Christie (Ed.), Pedagogy and the shaping of consciousness: Linguistic and social processes (pp. 123-155). Open Linguistics Series. Cassell.

Martin, J. R. (2013). Interviews with M. A. K. Halliday: Language turned back on himself. Bloomsbury.

Martin, J. R. (2014). Evolving systemic functional linguistics: Beyond the clause. Functional Linguist, 1(3). https://doi.org/10.1186/2196-419X-1-3

Martin J. R. \& Rose, D. (2008). Genre relations. Mapping culture. Equinox.

Martin,J. R., Maton, K. \& Doran, Y.(Eds).(2020). Academic discourse: An inter-disciplinary dialogue. In Accessing academic discourse: Systemic functional linguistics and legitimation code theory (pp. 1-31). Routledge. https://doi.org/10.4324/9780429280726-1

Matthiessen, C. \& Halliday, M. A. K. (2009). Systemic functional grammar: A first step into the theory. Higher Education Press.

Moyano, E. I. (2007). Enseñanza de la lectura y la escritura basada en la teoría de género y registro de la LSF: resultados de una investigación. Revista Signos, 40(65), 573-608. https://doi.org/10.4067/ S0718-09342007000300009

Moyano, E. I. (2010). Escritura académica a lo largo de la carrera: un programa institucional. Revista Signos, 43(74), 465-488. https://doi.org/10.4067/ S0718-09342010000500004

Moyano, E. I. (2017). Diseño e implementación de programas de lectura y escritura en el nivel universitario: 
principios y estrategias. Revista Lenguas Modernas, 50 (Segundo semestre 2017), 47-72. Federico Navarro (Ed.) Número especial monográfico "Enseñanza de la escritura en educación superior: el rol de la lectura y la escritura en la inclusión, calidad y equidad educativas".

Moyano, E. I. (forthcoming). 'Appliability' of SFL in two academic contexts in Argentina: Developing teaching academic genres in Spanish. In D. Caldwell, J. R. Martin, \& J. Knox (Eds.), Developing theory: A handbook in appliable linguistics and semiotics. Bloombsbury.

Painter, C. (1984). Into the mother tongue: A case study of early language development. Pinter.

Painter, C. (1991). Learning the mother tongue ( $2^{\text {nd }}$ Ed.). Deakin University Press.

Ramírez, A. (2018). Paraphrastic academic writing as entry point for first generation advanced bilingual college students. In R. Harman (Ed.), Bilingual learners and social equity: Critical approaches to systemic functional linguistics (pp. 179-198). Springer. https://doi. org/10.1007/978-3-319-60953-9_9

Ramírez, A. (2020). The case for culturally and linguistically relevant pedagogy: Bilingual reading to learn for Spanish-Speaking immigrant mothers. System, 95, article 102379. https://doi.org/10.1016/j. system.2020.102379

Ramírez, A. (forthcoming). Reading to learn, learning to teach: Emergent bilingual parents read in English to their young emergent bilingual children at home. In D. Caldwell, J. Martin, \& J. Knox (Eds.), Developing theory: A handbook in appliable linguistics and semiotics (p. 24). Bloomsbury.

Rose, D. \& Martin, J. R. (2012). Learning to write, reading to learn. Genre, knowledge and pedagogy in the Sydney School. Equinox.

Urrejola Coral, K. \& Vidal Lizama, M. (forthcoming). Opciones teóricas y didácticas en el programa PLEA para la enseñanza de la alfabetización disciplinar inicial. In E. I. Moyano \& M. Vidal Lizama (Eds.), Centros y programas de escritura en Latinoamérica: opciones teóricas y pedagógicas para la alfabetización académica. WAC Clearinghouse.

Veel, R. (1996). The Write it Right project — Linguistic modelling of secondary school and workplace discourse. In R. Whittaker, M. O’Donnell \& A. McCabe (Eds.), Language and literacy: Functional approaches (pp. 66-92). Continuum.

How to cite this article: Ramírez, A., Moyano, E. I., \& Martin, J. R. (2021). A language-based theory of learning in the disciplines and for acting in social life. Íkala, Revista de Lenguaje y Cultura, 26(1), 11-16. https://doi.org/10.17533/udea.ikala.v26n01a12 